\title{
The Impact of Ground Schools in a Collegiate Aviation Program on FAA Written Exam Scores
}

\author{
Triant G. Flouris \\ Auburn University
}

\begin{abstract}
This is a longitudinal study, tracing student FAA written exam test scores in a collegiate environment. The exams surveyed were administered in the War Eagle CATS testing center located at Auburn University from January 1, 1999 to December 31, 2000. The purpose of the study was to test the significance of ground schools offered at Auburn University on FAA written exam test scores. In addition, it examined the difference on test scores of Auburn students versus non-Auburn University students. The independent variable was set as the group corresponding to each FAA test ground school. The dependent variable was student performance based on each corresponding FAA written exam score. Statistical analysis revealed that there is no significance on the impact of the independent to the dependent variable, or the impact of ground schools on FAA written test performance is not significant.
\end{abstract}

\section{INTRODUCTION}

In theory, ground schools have the purpose of preparing students for FAA written exams in addition to teaching them the necessary knowledge to undertake the responsibilities of various tasks in aviation operations that correspond to the rating or license they seek. There has been a lot of discussion in collegiate aviation environments on the usefulness of ground schools as pedagogical tools. Are ground schools supposed to adhere to the expanded role of teaching students multidimensional aviation knowledge, which is fitting to a university environment? Or, are ground schools designed to teach students the skills they need to score well on their FAA written exams? Are both abovementioned goals compatible? Can they be achieved at the same time and in an effective manner? The above are valid questions that collegiate aviation programs address as they design syllabi and curricula.
To answer the above questions in an empirical way, we designed a study, which is based on scores collected by the War Eagle CATS Testing Center located at Auburn University. The study is a longitudinal one. It included scores over a period of two years, from January 1, 1999 to December 31, 2000. The origin of the data collection was somewhat arbitrary as January 1, 1999 was the date that we started keeping comprehensive records of test scores at the Center as we came up with the idea of the study. By December 312000 we had a large enough sample in each of the test categories we analyze in this paper to proceed with the statistical analysis in a way that valid results can be extracted.

To test our hypothesis, we collected results in two categories, which became our independent variables:

Category 1: Ground School $\left(\mathrm{y}_{1}\right)$ versus nonground school $\left(\mathrm{y}_{2}\right)$ attendee exam takers. Category 2: Auburn University student $\left(\mathrm{y}_{1}\right)$ versus non-Auburn university student exam takers $\left(\mathrm{y}_{2}\right)$. 
Our dependent variables (x) fell into 6 categories, each of them corresponding to the exam score on a specific FAA written exam.

$\mathrm{x}_{1}=$ Private Pilot Written

$\mathrm{x}_{2}=$ Instrument Rating Written

$\mathrm{x}_{3}=$ Commercial Pilot Written

$\mathrm{x}_{4}=$ Flight Instructor Written

$\mathrm{x}_{5}=$ Advanced Ground Instructor Written

$\mathrm{x}_{6}=$ Fundamentals of Instructing Written

As the sample sizes for ground school versus non-ground school attendees were different, to produce a valid comparison we used the sampling distribution of $\mathrm{x}_{1}-\mathrm{x}_{2}$ to develop an interval estimate of the difference between the two sample means. The sampling distribution of $\mathrm{x}_{1}-\mathrm{x}_{2}$ has the following properties:

$\mathrm{E}\left(\mathrm{x}_{1}-\mathrm{x}_{2}\right)=\mu_{1}-\mu_{2}$

As part of our study, to evaluate the differences between our two groups within each category $\left(\mathrm{C} 1 / \mathrm{G} 1-\mathrm{y}_{1}\right.$ : Exam takers who have taken a ground school and $\mathrm{C} 1 / \mathrm{G} 2-\mathrm{y}_{2}$ : Exam takers who have not taken a ground school and C2/G1-y: Auburn University Students and $\mathrm{C} 2 / \mathrm{G} 2-\mathrm{y}_{2}$ non-Auburn University students) in terms of their test scores in the standardized FAA exam, we have collected and analyzed the data described above. The FAA written scores are a major factor in assessing any significant differences on the effectiveness of the ground schools. The means of the two groups are as follows:

$\mu_{1}=$ the mean examination scores for the population of individuals in Group 1

(Category 1 and Category 2)

$\mu_{2}=$ the mean examination scores for the population of individuals in Group 2

(Category 1 and Category 2)
We begin with the tentative assumption of no difference in the quality of the two groups in each category. Hence, in terms of the mean examination scores, the null hypothesis is that $\mu_{1}-\mu_{2}=0$. If sample evidence leads to the rejection of this hypothesis, we will conclude that the mean examination scores differ for the two populations. This conclusion indicates a quality differential between the two groups, which may be attributed to whether they have attended or have not attended a ground school. The null and alternative hypothesis for both groups are written as follows:

Hol: $\mu_{1}-\mu_{2}=0$ and Ho2: $\mu_{1}-\mu_{2}=0$

Ha1: $\mu_{1}-\mu_{2}=0$ and Ha2: $\mu_{1}-\mu_{2}=0$

Following the conventional hypothesis testing procedure, we make the tentative assumption that Ho is true. Using the difference between the sample means as the point estimator of the difference between the population means, we consider the sampling distribution of $\mathrm{x}_{1}-\mathrm{x}_{2}$ when Ho is true. As the sample size is large $(n>30)$ the sampling distribution can be approximated by a normal probability distribution. The following test statistic is used for the approximation:

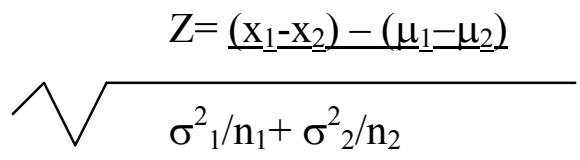

The value of $\mathrm{z}$ given by the above formula can be interpreted as the number of standard deviations $\mathrm{x}_{1}-\mathrm{x}_{2}$ is from the value of $\mu_{1}-\mu_{2}$ specified in Ho. The rejection rule is:

Reject Ho if $\mathrm{z}<-1.96$ or if $\mathrm{z}>+1.96$

\section{PRIVATE PILOT WRITTEN}

The analysis of Private Pilot Written Exam scores yielded a result that favors Auburn University students who take the 
written exam on their own versus students that take the exam as part of the private pilot ground school series. Additionally, nonAuburn University students achieved higher scores than Auburn University students. In analyzing the data it was important to look at both the mean and distribution of exam scores.

\begin{tabular}{|l|l|}
\hline Category & $\begin{array}{l}\text { Mean } \\
\text { Score }\end{array}$ \\
\hline Auburn Students & 84.0 \\
\hline $\begin{array}{l}\text { Students in AU Ground } \\
\text { School }\end{array}$ & 83.5 \\
\hline $\begin{array}{l}\text { Students not in AU Ground } \\
\text { School }\end{array}$ & 86.3 \\
\hline Non AU Student & 85.1 \\
\hline
\end{tabular}

According to the mean score analysis the difference between ground school students and non ground school students is 2.8 percent. The next step was to review the distributions of the four categories in order to determine whether the results of the mean analysis test are due to outliers. Additionally, a distribution of the data sets will yield the median values. The results of the distribution are in the Appendix, Table 1 .

The results of the distribution analysis show a wider range of scores for ground school students than non-ground school students. Also, the medians of the distributions are higher and closer than the averages. The median difference between ground school students and non-ground school students is only 1 percent. This means that the upper halves of test takers are similarly distributed. The chart above shows the score ranges. The non-ground school students have a narrow interquartile range and overall narrow distribution. The ground school students have a considerably wider distribution. The chart also reveals the presence of outliers. There are two outliers in the ground school class, and only one in the non-ground school class. However, these outliers are moderate, and after recalculating the data without them, the outliers were proven to have little impact on the results. The calculated $\mathrm{z}$ scores for both $\mathrm{Ha} 1$ and $\mathrm{Ha} 2$ show that the alternative hypothesis is both cases have to be rejected, so we can conclude that:

1. There is no significant difference between Auburn University student versus non-university student exam takers on their private pilot FAA written exam scores.

2. There is no significant statistical difference between ground school versus non-ground school attendee exam takers on their FAA private pilot exam scores.

The above statement may lead us to believe that attending ground schools has no impact on FAA written exam performance as far as the private pilot written is concerned.

\section{INSTRUMENT RATING WRITTEN}

The results from the written exam scores favored non-Auburn University students over Auburn University students by a wide margin. The difference between Auburn students who are enrolled in ground school and those who are not was small, but in favor of the non-ground school students. Both a mean and a distribution analysis were performed to compare the different categories.

\begin{tabular}{|l|l|}
\hline Category & Mean Score \\
\hline Auburn Students & 81.7 \\
\hline $\begin{array}{l}\text { Students in AU Ground } \\
\text { School }\end{array}$ & 81.5 \\
\hline $\begin{array}{l}\text { Students not in AU } \\
\text { Ground School }\end{array}$ & 82.8 \\
\hline Non AU Student & 89.8 \\
\hline
\end{tabular}


The difference between non-Auburn University students and Auburn University students is 8.1 percent in favor of the nonAuburn students. This gap is larger than any other exam analyzed. The difference between ground and non-ground students is 1.3 percent, which follows the overall pattern seen on all the exams analyzed. The next step was to perform a distribution analysis. The results of the distribution analysis are charted in the Appendix, Table 2.

The results indicated that the distribution differences are wider than the mean differences. The non-Auburn students outperformed all Auburn students by a median difference of 10.5 percent. Furthermore, the $1^{\text {st }}$ quartile score $(83.25$ percent) of non-Auburn test takers is higher than the median score for Auburn students (82 percent). This means that three fourths of the non-Auburn student test takers did better than half of the Auburn students.

One important change noted from the distribution analysis is that the median scores for non-ground and ground students are equal, with a value of 82 percent. This means that there is little difference between the expected scores of ground school and non-ground school students. The calculated $\mathrm{z}$ scores for both $\mathrm{Ha} 1$ and $\mathrm{Ha} 2$ show that the alternative hypothesis is both cases have to be rejected so we can conclude that:

1. There is no significant difference between Auburn University student versus non-university student exam takers on their instrument rating FAA written exam scores.

2. There is no significant statistical difference between ground school versus non-ground school attendee exam takers on their FAA instrument rating exam scores.
The above statement may lead us to believe that attending ground schools has no impact on FAA written exam performance as far as the instrument rating written is concerned.

\section{COMMERCIAL PILOT WRITTEN}

The disparity between Commercial Written Exam scores was slight. Overall, the non-students performed better than Auburn University students. The difference was small between test scores for students enrolled in the ground instruction course versus those who were not. To analyze the test results, both a mean and a distribution analysis were performed.

\begin{tabular}{|l|l|}
\hline Category & Mean Score \\
\hline Auburn Students & 89.1 \\
\hline $\begin{array}{l}\text { Students in AU Ground } \\
\text { School }\end{array}$ & 88.8 \\
\hline $\begin{array}{l}\text { Students not in AU Ground } \\
\text { School }\end{array}$ & 89.9 \\
\hline Non AU Student & 92.6 \\
\hline
\end{tabular}

As seen in the table, the non-students scored an average score 3.5 percent higher than Auburn students. The difference between ground school and non-ground school students was 1.1 percent, which follows the trend witnessed on other exams. Next a distribution analysis was conducted to identify any outliers or distribution trends that would better explain the results. The distributions are in the Appendix, Table 3.

The distribution analysis shows that non-students performed better than the mean analysis stated. The median test score for non-students is 96 percent, which is considerably higher than the mean of 92.6 percent. The reason for the disparity is the extreme outlier that is present on the boxplot (Appendix, Table 3). The median difference between non-students to students is 5.5 percent, which is a wider gap than the mean analysis yielded. The median difference between ground school and non-ground 
school students is small, one percent, and is in favor of the non-ground school students. This difference is similar to differences noted on all other exams analyzed. The calculated $\mathrm{z}$ scores for both $\mathrm{Ha} 1$ and $\mathrm{Ha} 2$ show that the alternative hypothesis is both cases have to be rejected, so we can conclude that:

1. There is no significant difference between Auburn University student versus non-university student exam takers on their commercial pilot FAA written exam scores.

2. There is no significant statistical difference between ground school versus non-ground school attendee exam takers on their FAA commercial pilot exam scores.

The above statement may lead us to believe that attending ground schools has no impact on FAA written exam performance as far as the commercial pilot written is concerned.

\section{FUNDAMENTALS OF INSTRUCTING WRITTEN}

The results for the Fundamentals of Flight Instructing Exam favor the nonground school students over the ground school students. Additionally, the nonstudent test takers achieved better scores than Auburn University Students. These results are similar to results noted on the other exams. The means are shown below.

The mean difference between student test takers was present, but slight with a 2.6 percent difference. Non-Auburn University

Students did very well on this exam, with an average score of 96.4 percent. Next, the distributions were analyzed. The results are in the Appendix Table 4. As expected from the average scores, the non-students had a very narrow distribution, but did have a

\begin{tabular}{|l|l|}
\hline Category & Mean Score \\
\hline Auburn Students & 91.5 \\
\hline $\begin{array}{l}\text { Students in AU } \\
\text { Ground School }\end{array}$ & 90.9 \\
\hline $\begin{array}{l}\text { Students not in AU } \\
\text { Ground School }\end{array}$ & 93.5 \\
\hline Non AU Student & 96.4 \\
\hline
\end{tabular}

surprising two outliers.

The main point that the box plots bring up is the presence of extreme outliers, especially the score of 50 percent by one of the ground school students (Appendix, Table 4). When that outlier is removed the average for ground students is raised to a 92.7 percent, which means that the two groups are not as far apart as the mean analysis suggests. The other point of interest is the length of the tail for ground students. The tail is longer, meaning that the lower 25 percent of test takers scored within a wide range, which skewed the results achieved by the upper 75 percent. Overall, this exam exemplifies the results achieved on other exams. The calculated $\mathrm{z}$ scores for both $\mathrm{Ha} 1$ and $\mathrm{Ha} 2$ show that the alternative hypothesis is both cases have to be rejected so we can conclude that:

1. There is no significant difference between Auburn University student versus non-university student exam takers on their fundamentals of instructing FAA written exam scores.

2. There is no significant statistical difference between ground school versus non-ground school attendee exam takers on their FAA fundamentals of instructing exam scores. 
The above statement may lead us to believe that attending ground schools has no impact on FAA written exam performance as far as the fundamentals of instructing written is concerned.

\section{FLIGHT INSTRUCTOR WRITTEN}

The difference between test takers was slight, but still in favor of the students taking the exam while not enrolled in a ground school. As seen in the mean analysis summary below, the Auburn Students without ground school achieved higher exam scores than all other categories. The non-student test takers did worse, which warranted further inspection. The number of non-student test takers was small and one score was considerably lower than the rest, which brought the average down.

\begin{tabular}{|l|l|}
\hline Category & $\begin{array}{l}\text { Mean } \\
\text { Score }\end{array}$ \\
\hline Auburn Students & 87.6 \\
\hline $\begin{array}{l}\text { Students in AU Ground } \\
\text { School }\end{array}$ & 85.9 \\
\hline $\begin{array}{l}\text { Students not in AU } \\
\text { Ground School }\end{array}$ & 90.9 \\
\hline Non AU Student & 87.4 \\
\hline
\end{tabular}

As seen above, the students without ground school achieved scores 5 percent higher than students in ground school. The next step was to examine the distributions of the data, which are in the Appendix, Table 5. The difference between student groups held up, but the difference between nonstudents and non-ground students disappeared, as the medians are equal.

The distributions offer more explanation for the results. The NonAuburn Student category did well, but the lower 50 percent brought the average down considerably. The students not in ground school have a narrow distribution without outliers. The differences that exist for this exam follow the others with the exception of the mean score difference of non-student test takers, which was explained by the one low score that brought the average down. The calculated $\mathrm{z}$ scores for both $\mathrm{Ha} 1$ and $\mathrm{Ha} 2$ show that the alternative hypothesis is both cases have to be rejected so we can conclude that:

1. There is no significant difference between Auburn University student versus non-university student exam takers on their flight instructor FAA written exam scores.

2. There is no significant statistical difference between ground school versus non-ground school attendee exam takers on their FAA flight instructor exam scores.

The above statement may lead us to believe that attending ground schools has no impact on FAA written exam performance as far as the flight instructor written is concerned.

\section{ADVANCED GROUND INSTRUCTOR WRITTEN}

The Advanced Ground Instructor Exam scores were largely in favor of nonAuburn students. When Auburn University students were compared to non-Auburn students, the students taking the exam as part of a ground school class did considerably poorer than those who did not. The following analysis breaks the scores down for the mean and distribution (for the distribution see Appendix, Table 6).

\begin{tabular}{|l|l|}
\hline Category & Mean Score \\
\hline Auburn Students & 85.2 \\
\hline $\begin{array}{l}\text { Students in AU Ground } \\
\text { School }\end{array}$ & 81.8 \\
\hline $\begin{array}{l}\text { Students not in AU Ground } \\
\text { School }\end{array}$ & 91 \\
\hline Non AU Student & 94 \\
\hline
\end{tabular}


The mean scores are heavily in favor of non-students and students not in ground school. Students taking this test on their own scored, on average, 9.2 percent higher than students who attended a ground school. Before taking the mean difference too far, it is important to examine the distributions. The distributions are listed in the Appendix, Table 6.

The quartile ranges and the medians give more insight into the characteristics of the data. The medians between ground and non-ground school students are only 6.5 percent apart, which is considerably closer than the mean analysis indicated. The box plots (Table 6, Appendix) further demonstrate the effect of a wide lower quartile range. The wide interquartile range and extended lower whisker on the ground school plot shows that the lower half of ground school test takers were considerably more spread out than the lower half of the non-ground school test takers. It should be noted that out of tests chosen for analysis this one had the fewest scores to analyze, with a total of 43 tests taken. Because of the small number a few low scores may significantly skew the results. The calculated z scores for both Ha1 and Ha2 show that the alternative hypothesis is both cases have to be rejected, so we can conclude that:

1. There is no significant difference between Auburn University student versus non-university student exam takers on their advanced ground instructor FAA written exam scores.

2. There is no significant statistical difference between ground school versus non-ground school attendee exam takers on their FAA advanced instructor exam scores.

The above statement may lead us to believe that attending ground schools has no impact on FAA written exam performance as far as the advanced ground instructor written is concerned.

\section{CONCLUSION}

The data analysis for each exam reveals that there is no statistical significance in the impact of ground schools on the FAA test scores of a sample of test takers at War Eagle CATS Testing Center located at Auburn University. Our data analysis also shows that there is no statistical significance in the impact of being a University student (Auburn University) on the FAA test scores of a sample of test takers at War Eagle Testing Center. The study only looked at a period of two years, from January 11999 to December 312000. Several conclusions may be drawn from the above analysis that have to do with the effectiveness of ground schools in preparing students for FAA written exams. More indepth, careful and comprehensive studies need to be conducted before such conclusions are drawn. We in no way claim that the findings of our analysis are universally applicable. 


\section{APPENDIX}

$\underline{\text { Table } 1}$

\section{Private Pilot Written Results}

\begin{tabular}{|r|c|c|c|c|}
\hline & $\begin{array}{l}\text { Auburn } \\
\text { Students }\end{array}$ & $\begin{array}{l}\text { In AU Ground } \\
\text { School }\end{array}$ & $\begin{array}{l}\text { Not in AU Ground } \\
\text { School }\end{array}$ & $\begin{array}{l}\text { Non AU } \\
\text { Student }\end{array}$ \\
\hline First Quartile & 78.00 & 78.00 & 82.50 & 78.50 \\
\hline Median & 86.00 & 86.00 & 87.00 & 88.00 \\
\hline Third Quartile & 92.00 & 90.00 & 93.00 & 94.50 \\
\hline $\begin{array}{r}\text { Interquartile } \\
\text { Range }\end{array}$ & 14.00 & 12.00 & 10.50 & 16.00 \\
\hline Mean & 84 & 83.5 & 86.3 & 85.1 \\
\hline $\begin{array}{r}\text { Moderate Outliers } \\
(\Delta)\end{array}$ & 1 & 2 & 1 & 0 \\
\hline $\begin{array}{r}\text { Extreme Outliers } \\
(\mathbf{\Delta})\end{array}$ & 0 & 0 & 0 & 0 \\
\hline
\end{tabular}

\section{Private Pilot Written Distribution}

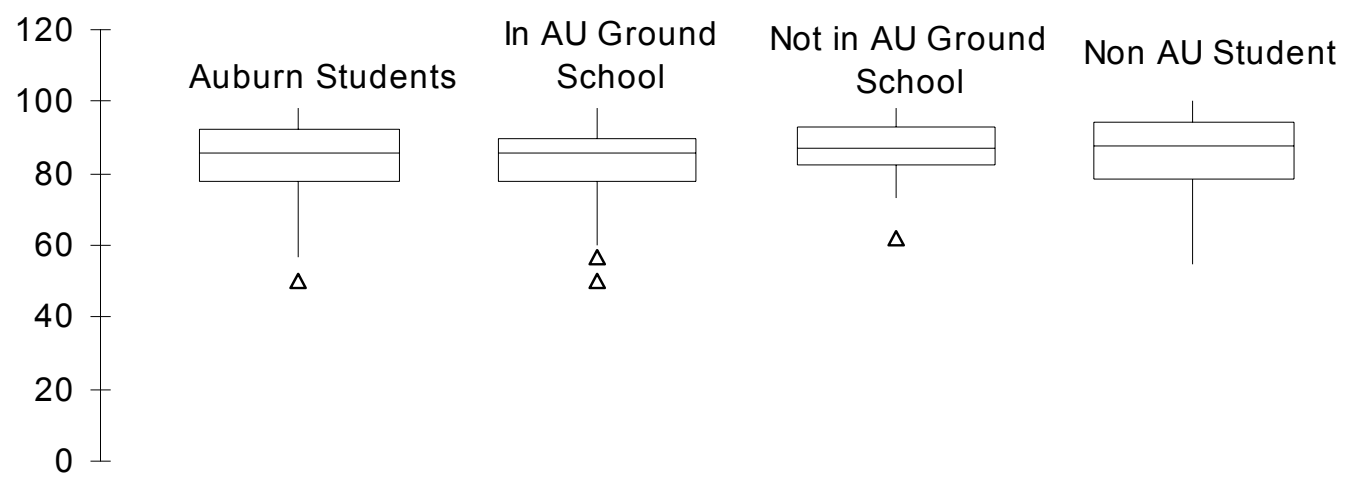


$\underline{\text { Table } 2}$

Instrument Rating Written Results

\begin{tabular}{|r|c|c|c|c|}
\hline & $\begin{array}{l}\text { luburn } \\
\text { Students }\end{array}$ & $\begin{array}{l}\text { In AU Ground } \\
\text { School }\end{array}$ & $\begin{array}{l}\text { Not in AU Ground } \\
\text { School }\end{array}$ & $\begin{array}{l}\text { Non AU } \\
\text { Student }\end{array}$ \\
\hline First Quartile & 75.00 & 73.00 & 78.00 & 83.25 \\
\hline Median & 82.00 & 82.00 & 82.00 & 92.50 \\
\hline $\begin{array}{r}\text { Third Quartile } \\
\text { Interquartile } \\
\text { Range }\end{array}$ & 15.00 & 90.00 & 88.50 & 97.25 \\
\hline Mean & 81.7 & 17.00 & 10.50 & 14.00 \\
\hline $\begin{array}{r}\text { Moderate Outliers } \\
(\Delta)\end{array}$ & 2 & 81.5 & 82.8 & 89.8 \\
\hline $\begin{array}{r}\text { Extreme Outliers } \\
(\mathbf{\Delta})\end{array}$ & 0 & 0 & 0 & 0 \\
\hline
\end{tabular}

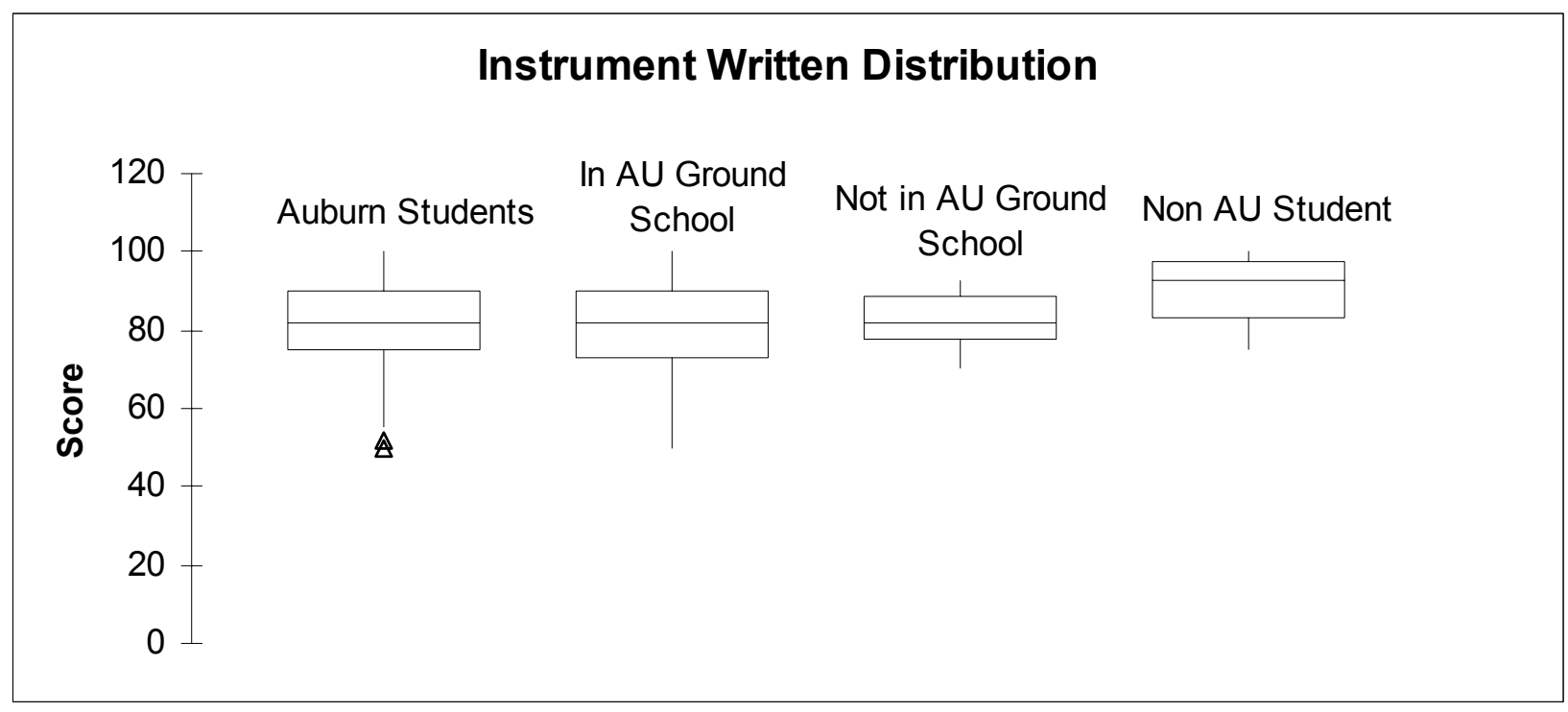


Table 3

Commercial Pilot Written Results

\begin{tabular}{|r|c|c|c|c|}
\hline & $\begin{array}{l}\text { luburn } \\
\text { Students }\end{array}$ & $\begin{array}{l}\text { In AU Ground } \\
\text { School }\end{array}$ & $\begin{array}{l}\text { Not in AU Ground } \\
\text { School }\end{array}$ & $\begin{array}{l}\text { Non AU } \\
\text { Student }\end{array}$ \\
\hline First Quartile & 85.0000 & 85.0000 & 89.2500 & 92.5000 \\
\hline Median & 90.5000 & 89.5000 & 91.5000 & 96.0000 \\
\hline Third Quartile & 94.0000 & 93.0000 & 94.7500 & 97.0000 \\
\hline $\begin{array}{r}\text { Interquartile } \\
\text { Range }\end{array}$ & 9.0000 & 8.0000 & 5.5000 & 4.5000 \\
\hline Mean & 89.1 & 88.8 & 89.9 & 92.6 \\
\hline $\begin{array}{r}\text { Moderate Outliers } \\
(\Delta)\end{array}$ & 0 & 0 & 1 & 0 \\
\hline $\begin{array}{r}\text { Extreme Outliers } \\
(\Delta)\end{array}$ & 0 & 0 & 1 & 1 \\
\hline
\end{tabular}

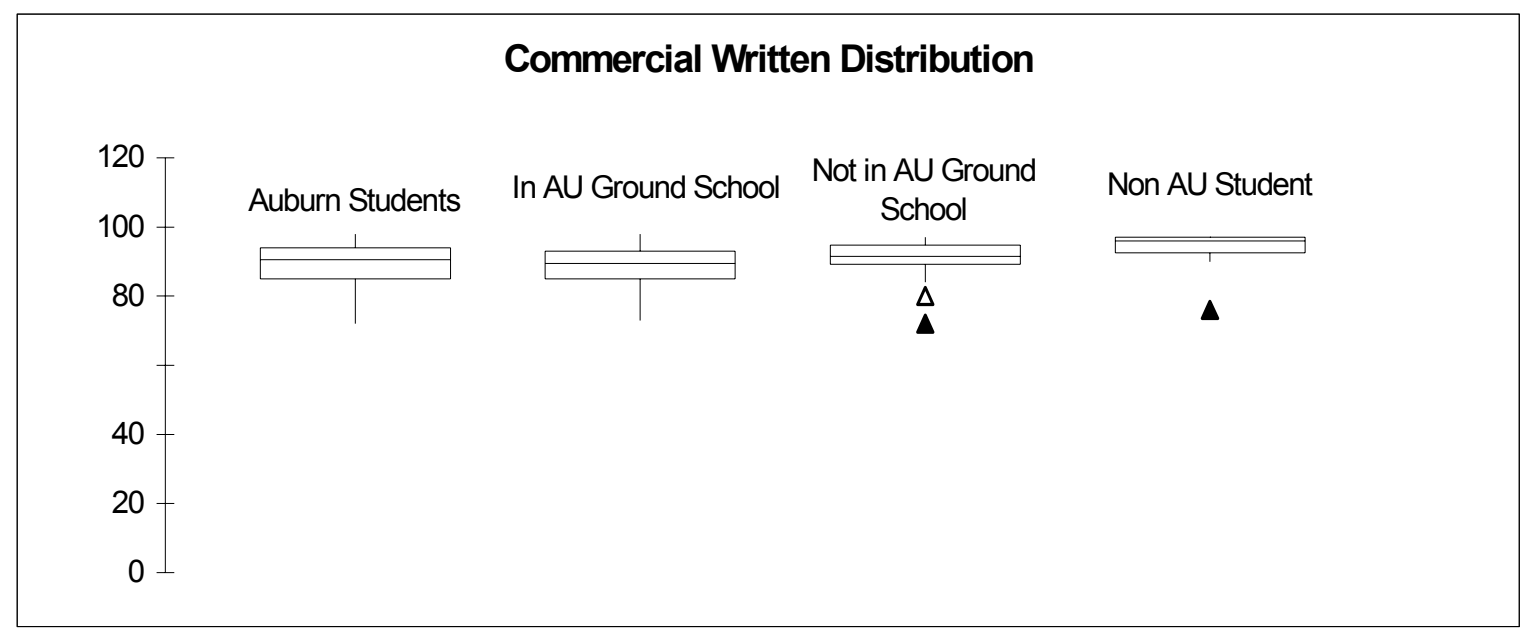




\section{$\underline{\text { Table } 4}$}

Fundamentals of Instructing Written Results

\begin{tabular}{|r|c|c|c|c|}
\hline & $\begin{array}{l}\text { Auburn } \\
\text { Students }\end{array}$ & $\begin{array}{l}\text { In AU Ground } \\
\text { School }\end{array}$ & $\begin{array}{l}\text { Not in AU Ground } \\
\text { School }\end{array}$ & $\begin{array}{l}\text { Non AU } \\
\text { Student }\end{array}$ \\
\hline First Quartile & 87.0 & 87.0 & 90.5 & 98.0 \\
\hline Median & 94.0 & 94.0 & 96.0 & 98.0 \\
\hline $\begin{array}{r}\text { Third Quartile } \\
\text { Interquartile } \\
\text { Range }\end{array}$ & 11.0 & 98.0 & 98.0 & 100.0 \\
\hline Mean & 91.5 & 11.0 & 7.5 & 2.0 \\
\hline $\begin{array}{r}\text { Moderate Outliers } \\
(\Delta)\end{array}$ & 0 & 90.9 & 93.5 & 96.4 \\
\hline $\begin{array}{r}\text { Extreme Outliers } \\
(\mathbf{\Delta})\end{array}$ & 1 & 0 & 0 & 0 \\
\hline
\end{tabular}

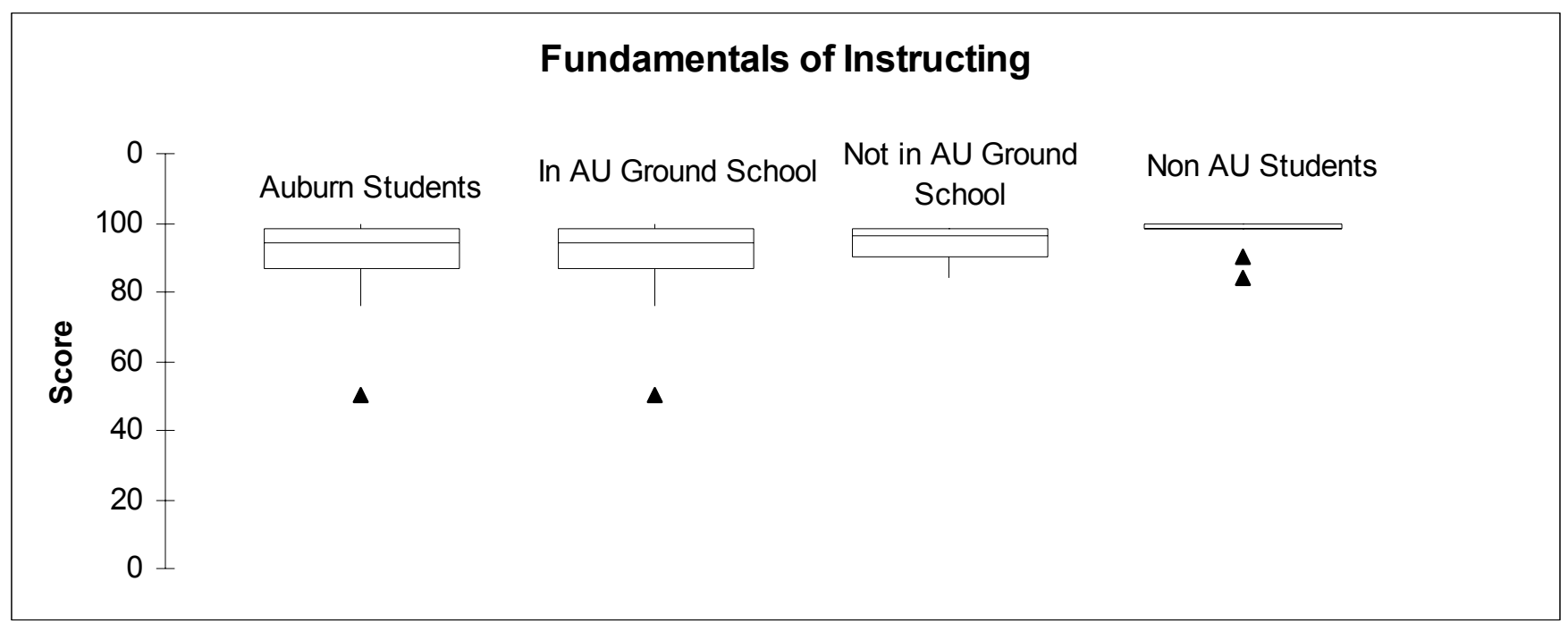


$\underline{\text { Table } 5}$

Flight Instructor Written Results

\begin{tabular}{|r|c|c|c|c|}
\hline & $\begin{array}{l}\text { Auburn } \\
\text { Students }\end{array}$ & $\begin{array}{l}\text { In AU Ground } \\
\text { School }\end{array}$ & $\begin{array}{l}\text { Not in AU Ground } \\
\text { School }\end{array}$ & $\begin{array}{l}\text { Non AU } \\
\text { Student }\end{array}$ \\
\hline First Quartile & 81.3 & 80.0 & 89.0 & 83.0 \\
\hline Median & 89.0 & 87.5 & 92.0 & 92.0 \\
\hline $\begin{array}{r}\text { Third Quartile } \\
\text { Interquartile } \\
\text { Range }\end{array}$ & 11.5 & 91.5 & 92.8 & 94.0 \\
\hline Mean & 87.6 & 11.5 & 3.8 & 11.0 \\
\hline $\begin{array}{r}\text { Moderate Outliers } \\
(\Delta)\end{array}$ & 0 & 85.9 & 90.9 & 87.4 \\
\hline $\begin{array}{r}\text { Extreme Outliers } \\
(\mathbf{\Delta})\end{array}$ & 0 & 0 & 0 & 0 \\
\hline
\end{tabular}

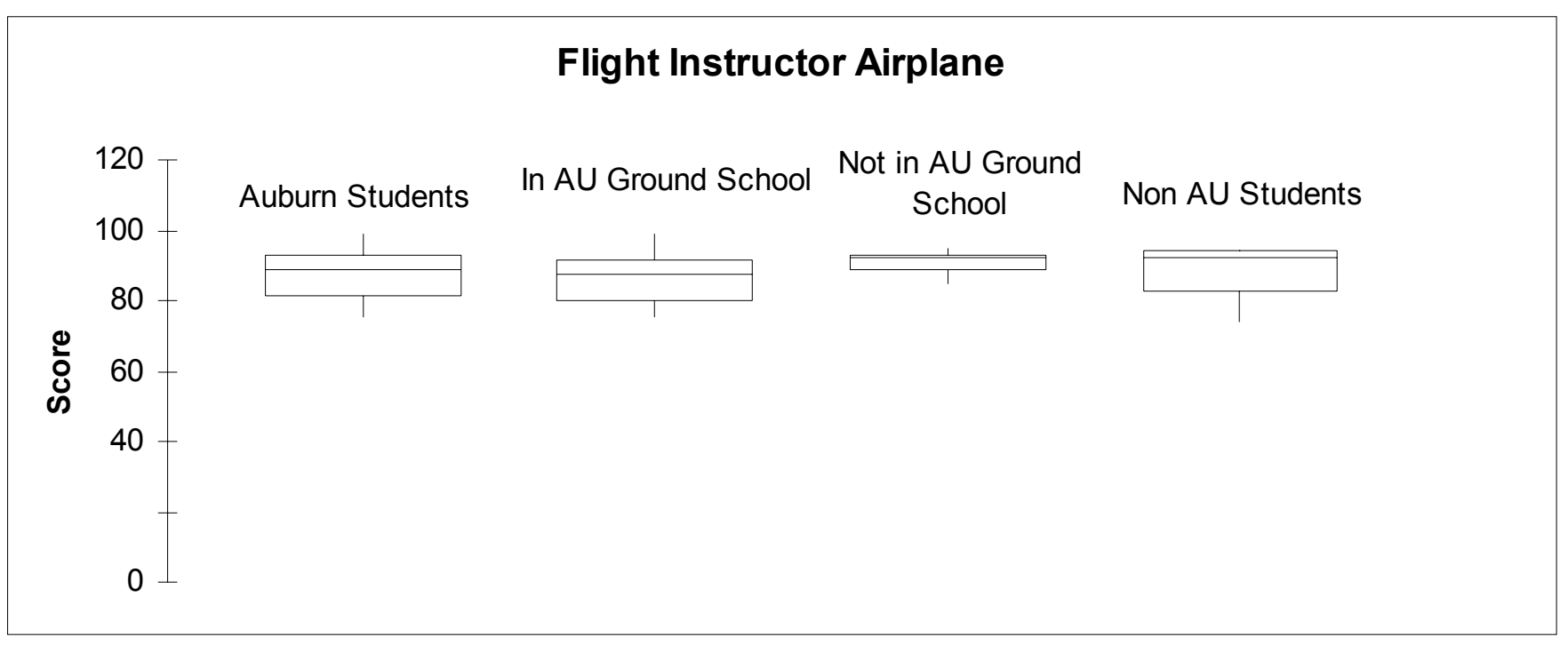




\section{$\underline{\text { Table } 6}$}

Advanced Ground Instructor Written Results

\begin{tabular}{|r|c|c|c|c|}
\hline & $\begin{array}{l}\text { Auburn } \\
\text { Students }\end{array}$ & $\begin{array}{l}\text { In AU Ground } \\
\text { School }\end{array}$ & $\begin{array}{l}\text { Not in AU Ground } \\
\text { School }\end{array}$ & $\begin{array}{l}\text { Non AU } \\
\text { Student }\end{array}$ \\
\hline First Quartile & 81.5 & 73.0 & 87.0 & 89.0 \\
\hline Median & 85.0 & 83.5 & 90.0 & 94.0 \\
\hline $\begin{array}{r}\text { Third Quartile } \\
\text { Interquartile } \\
\text { Range }\end{array}$ & 93.5 & 89.0 & 96.0 & 98.0 \\
\hline Mean & 85.2 & 16 & 9 & 9 \\
\hline $\begin{array}{r}\text { Moderate Outliers } \\
(\Delta)\end{array}$ & 1 & 81.8 & 91 & 94 \\
\hline $\begin{array}{r}\text { Extreme Outliers } \\
(\mathbf{\Delta})\end{array}$ & 0 & 0 & 0 & 0 \\
\hline
\end{tabular}

\section{Advanced Ground Instructor}

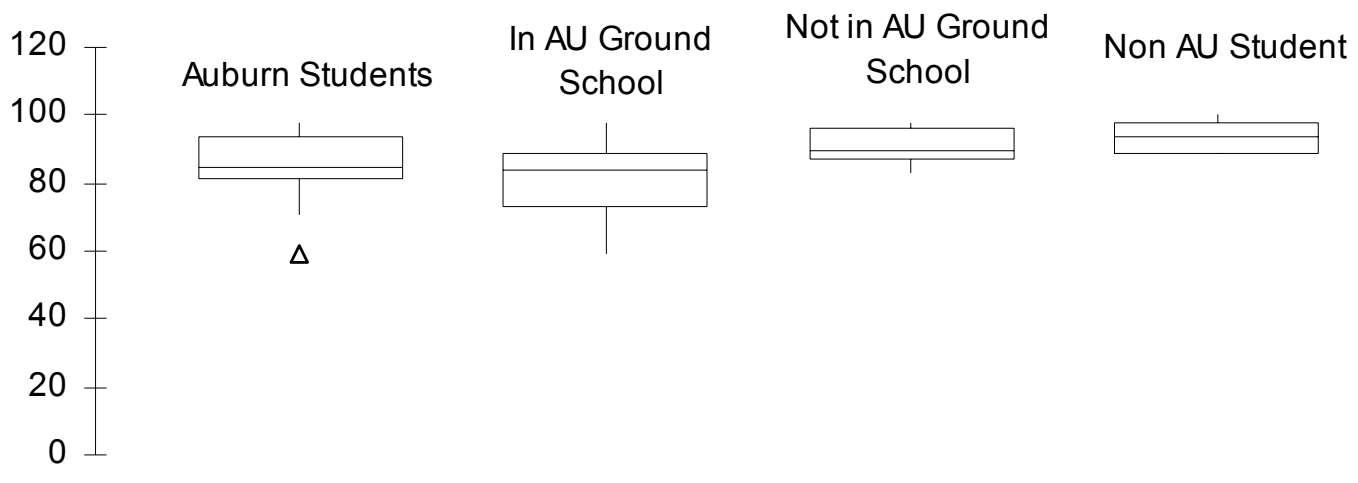

